\title{
An Exploration of the Canon of Hausa Prose Fiction in Hausa Language and Translation: The Literary Contest of 1933 as a Historical Reference
}

\author{
Chaibou Elhadji Oumarou \\ Department of English, Université Abdou Moumouni, Niamey, Niger \\ Email: chaiboue@yahoo.fr
}

How to cite this paper: Oumarou, C. E. (2017). An Exploration of the Canon of Hausa Prose Fiction in Hausa Language and Translation: The Literary Contest of 1933 as a Historical Reference. Advances in Literary Study, 5, 1-16.

http://dx.doi.org/10.4236/als.2017.51001

Received: October 17, 2016

Accepted: January 1, 2017

Published: January 4, 2017

Copyright $\odot 2017$ by author and Scientific Research Publishing Inc. This work is licensed under the Creative Commons Attribution International License (CC BY 4.0).

http://creativecommons.org/licenses/by/4.0/

\begin{abstract}
The paper premises that the literary contest of 1933 has been a very important historical reference and a determining condition for the emergence of the canon of Hausa prose fiction (Furniss, 1991, 1996). As a consequence, my exploration is going to be directed first toward the role of the British colonial administration as the organizer of the literary contest and then toward the role played by the university critics in transforming the winning essays into a corpus of literary masterpieces, thus creating some of the conditions for the emergence and consolidation of the canon of the Hausa prose fiction in both the Hausa language and in translation into English.
\end{abstract}

\section{Keywords}

Exploration, Canon, Hausa, Prose Fiction, Translation

\section{Introduction}

In the article entitled "Qu'est-ce qu'un classique africain?" published in 2005, Bernard Mouralis argues that such a question needs to be contextualized. Among the many reasons that justify such a contextualization, there is the language used by the authors as well as the place and function of that language within the communities of the writers and the critics.

Jean Dérive (2005: pp. 28-29) also draws attention on the importance of language in the search for identity in African literatures in European languages in particular and how the language issue should affect the choice of critical approaches by the critics:

In this respect, he argues, the African literatures in European languages of- 
ten suffered, because of the loan of a language which had its own literary traditions, of a problem of identity which they tried to solve in diverse manners, a concern which is a determining factor for the critical approach that it is possible to use to analyze them. This is not the case with African literatures in African languages which, because they do not face any identity problem, at least not in the same terms, develop according to other stakes which the critical approach has to take into account. It is however advisable to distinguish, in the literary production in African languages, the case of the oral literature and that of the written literature (My translation) ${ }^{1}$

As a result, Jean Dérive concludes, "whatever the theoretical supports considered, is recognized the necessity of envisaging the particular conditions according to which is produced and consumed a literary work, in order to establish a relevant problematic concerning its approach" ("Quels que soient les appuis théoriques pris, est reconnue la nécessité d'envisager les conditions particulières selon lesquelles est produite et consommée une cuvre littéraire, afin d'établir une problématique pertinente de son approche") (28; my translation; emphasis added).

Graham Furniss (1996: viii), on his part, complains about the marginalization of African literatures in African languages in the debate on post-colonial literatures in Africa. He points out the existence of a similar debate that has taken place in African languages, mostly in Hausa and which is less known by critics and commentators of world literatures because of their total or partial ignorance about the African languages. Echoing Jean Dérive quoted above, Furniss defends the existence of an "'authentic' indigenous tradition" and a debate about the nature of the colonial experience in the Hausa language literature, "not as a peripheral satellite world struggling to find itself in relationship to English and European culture [as Ashcroft, Griffins and Tiffin (1989) contend], but as a vigorous arena in its own right relating to its own cosmopolitan traditions of cultural thought' (Furniss, 1996: ix; emphasis added).

Janos Riesz (2011) expands the reflection on the issue of both the contextualization as pointed out by Mouralis above and of the marginalization of African literatures in African languages about which Furniss complains by adding more questions that bring into focus the need to distinguish the African literatures written in the African languages from the ones written in the European languages. In his article titled "A propos des 'classiques africains'. Quels modèles pour un canon des littératures africaines?", Riesz claims that:

The most important, as Mouralis claims, is to contextualize the questions

${ }^{1}$ A cet égard, he argues, les littératures africaines en langues européennes ont souvent souffert, du fait de l'emprunt d'une langue qui avait ses propres traditions littéraires, d'un problème d'identité qu'elles ont cherché à résoudre de diverses manières, préoccupation qui est un facteur déterminant pour l'approche critique qu'il est possible d'en faire. Il n'en va pas de même des littératures en langues africaines qui, du fait qu'elles ne connaissent pas ce problèmes identitaire, en tout cas pas dans les mêmes termes, s'élaborent selon d'autres enjeux dont l'approche critique doit tenir compte. Il convient cependant de distinguer, dans la production littéraire en langues africaines, le cas de la littérature orale et celui de la littérature écrite. 
that concern that quality of the "classics." The first question to be asked is naturally: "classic" in relation to which group or sub-group? Is it in relation to national literature? African literature? World literature? The canon in question is it limited to one language? Is it defined in relation to an epoch (a century, for instance), or in relation to a historical moment? Or does it concern a whole literary history that spreads over several centuries? (147; my translation) $)^{2}$.

To answer these questions, Riesz examined the Dictionnaire des écrivains francophones classiques. Afrique sub-saharienne, Caraibe, Maghreb, Machreck, Océan Indien (2010). Forty eight (48) university scholars mostly from France, Africa, and the Caribbean participated in the writing of the dictionary with their respective articles on one hundred and five (105) authors. According to Riesz, the university critics unanimously accepted six (6) criteria to make an author a classic or canonized:

1) aesthetic judgments based on original and innovative writing or style; 2 ) innovations (or ruptures) about the themes treated or the manner of treating them; 3) the relative importance of the authors in relation to their "national" or even "ethnic" literature or culture; 4) the presence of the authors in school and/or university programs; 5) their fame beyond the borders of their countries and the number of translations of their works in other languages; 6 ) the founding role of the author (or of a work), which is the origin of a new orientation (stylistic or thematic) or of a new accent in the respective literatures (160; my translation) ${ }^{3}$.

Riesz and Mouralis also claim that modern African literatures written in the European languages in particular are mature enough to have their own classics. In fact, for Mouralis, "the literary production of Africa has for a long time stopped being 'young' or 'emergent' and, in this respect, it satisfies the famous obligation of duration that generations of critics or professors have considered as a necessary condition for the emergence of 'classical texts" (emphasis added; My translation $)^{4}$. Not long ago, as Mouralis recalls, such a statement inspired Paulin Joachim, editor of the monthly Bingo, with a very negative commentary ${ }^{2}$ Le tout, comme le dit Mouralis, est de contextualiser les questions qui concernent cette qualité des "classiques". La première question qu'il faut poser est évidemment: “classique" par rapport à quel ensemble ou sous-ensemble? Est-ce par rapport à une littérature nationale? continentale? mondiale? Le canon envisagé est-il limité à une seule langue? se définit-il par rapport à une époque (un siècle, par exemple), ou à un moment historique? Ou concerne-t-il toute une histoire littéraire s'étendant à travers plusieurs siècles?

${ }^{3} 1$ ) des jugements esthétiques à partir d'une écriture ou d'un style originaux et novateurs; 2) des innovations (ou ruptures) dans les thèmes traités ou dans la manière de les traiter; 3) l'importance relative des auteurs par rapport à leur littérature ou culture "nationale", voire "ethnique"; 4) la présence des auteurs dans les programmes scolaires et/ou la recherche universitaire; 5) leur rayonnement au-delà des frontières de leurs pays et le nombre de leurs traductions en d'autres langues; 6) le rôle fondateur de l'auteur (ou d'une œuvre), qui est à l'origine d'une nouvelle orientation (stylistique ou thématique) ou d'un accent nouveau dans les littératures respectives (160).

4"La production littéraire de 1 A frique a cessé depuis longtemps d'être "jeune" ou "émergente" et, à cet égard, elle satisfait à la fameuse obligation de durée que des générations de critiques ou de professeurs ont considéré comme une condition nécessaire à lapparition de textes "classiques". (36). 
about the early European publishers who tried to bring to the world some of the African novelists writing in French and whom they considered as classics.

As a matter of fact, in an article titled "Méfions-nous des marchands de livres" (in Editorial africain, Strasbourg Imprimerie des Dernières Nouvelles de Strasbourg, 1967. $p 137$ et $p$ 138-139) Joachim accuses Publisher Julliard of trying to make money by creating "literary fames without much effort" and "of invading and" monopolizing the African market of books. (my translation) ("des gloires littéraires à trop bon compte" and "envahir et" [...] monopoliser le marché africain du livre." (Mouralis, 2006: p. 35) Joachim could not accept that the term "classic" be associated with African authors who did not deserve, in his view, to be compared to the European classics such as Shakespeare, Tolstoy, or Goethe:

It is a crime, Joachim wrote with indignation, against intelligence to want to dethrone Balzac and Flaubert by mediocre makers of negro-African books just to exploit the nascent nationalism of the new Negro nations. [...] Classics of the world, L'Enfant Noir [The Black Child], Un piège sans fin [An Endless Trap], L'aventure ambigüe [Ambiguous Adventure], among others, put side by side with the immortal masterpieces of Victor Hugo, Shakespeare, Tolstoy and Goethe? We have the impression that we are being laughed at. Better, it seems that some want to maintain us far from the big spiritual feasts of the universe by devilishly illustrating our intellectual infantilism and I do not know which congenital incapacity which was for a very long time the cliché used by those who had the mission to downgrade the negro people and their cultures to the level of insignificant junks only good for filling up the gallery (my translation, emphasis added $)^{5}$.

Even if it is still possible to find scholars who share Joachim's opinion today, many scholars will rather agree with Mouralis and Riesz. The latter are also right in affirming that the oral and written literatures in African languages, often published locally, are seldom known internationally; despite the fact that in languages such as Hausa, Swahili and Yoruba the literary production is quite significant and also meets at least some of the criteria, if not all of them, to have their own classics or canons. For example, a few authors writing in Hausa have already achieved some degree of success mostly in Nigeria: witness the recent publication of an epoch-making critical work on the novel Ruwan Bagaja by Abubakar Imam. The sub-title itself is revealing: Eight Decades of a Hausa Masterpiece in Prose (1933-2013). "Masterpiece" here is another term for canon or

${ }^{5}$ C'est un crime, Joachim wrote with indignation, contre lesprit que de vouloir détrôner Balzac et Flaubert par de piètres faiseurs de livres négro-africains à seule fin d’ exploiter le nationalisme, il est vrai, exacerbé des nouvelles nations nègres. [...] Classiques du monde, L'Enfant Noir, Un piège sans fin, L'aventure ambigüe, entre autres, jouxtant les chefs-d cuvre immortels de Victor Hugo, de Shakespeare, de Tolstoï et de Goethe? Nous avons l'impression qu'on se moque de nous. Mieux, il semble que Pon veuille nous maintenir loin des grandes fêtes spirituelles de l univers en illustrant diaboliquement notre infantilisme intellectuel et je ne sais quelle incapacité congénitale qui fut très longtemps la tarte à la crème de ceux qui avaient pour mission de ravaler les peuples négro-africains et leur culture au rang de pacotilles insignifiantes et tout juste bonnes à amuser la galerie (ibid., C’est Mouralis qui a souligné). 
classic and the fact that the articles that make up the book are written either in Arabic, English, French, or Hausa is, in the words of one of the general editors, Aliyu Muhammad Bunza, a celebration of eighty years of Ruwan Bagaja's "active service in the African literary history" and "academic relevance" (v) in Hausa studies.

What is more, "In its effort to uplift the academic status of Arts and Humanities, Bunza explains, the Umaru Musa Yar'adua University, Katsina, signed a memorandum of understanding [MOU] with the University of Kairo, a pioneer University per Academic excellence in sub-Saharan Africa. The main objective of the (MOU) is to raise teaching and research to world standard. ... [T] his publication is a commitment to that regard" (v).

In light of the above literature review on the debate on canon in African literatures in general and on Hausa literature in the Hausa language in particular, this paper premises that the literary contest of 1933 has been a very important historical reference and a determining condition for the emergence of the canon of Hausa prose fiction. As a consequence, the paper will focus essentially on the winning essays of the contest and on how at least some of them, like Ruwan Bagaja, have been acclaimed by the university critics as the "masterpieces" of the Hausa prose fiction. These winning essays are Ruwan Bagaja by Abubakar Imam; Gandoki by Bello Kagara; Shaihu Umar by Abubakar Tafawa Balewa; Idon Matambayi by Muhammadu Gwarzo and Jiki Magayi by John Tafida and Rupert East (Furniss, 19967: Chapter 2). In this chapter Furniss also provides excellent summaries of each winning novel which readers can consult because I cannot reproduce them here for space limitation inherent in this kind of article.

My exploration of these prose fictions as Hausa classics is going to be directed first toward the role of the British colonial administration as the organizer of the literary contest. The exploration of the role of the British colonial administration is relevant because it will allow a foregrounding of the positive impact of the role of some progressive British colonial administrators on the one hand. On the other hand, it will also highlight the difference between the French and the British cultural policies in their respective colonial empires and the different impacts of those policies on the promotion of the locale cultures through literary activities in local languages (see my three articles in the reference for detailed analysis on this issue).

Then I will look at the role played by the university critics in transforming the winning essays in the Hausa language into a corpus of literary masterpieces like Ruwan Bagaja and Shaihu Umar. In so doing, they have created some of the

\footnotetext{
${ }^{6}$ See I. Adamu's PhD dissertation on two out of the five winning essays: Adamu, I. (2002), "A Stylistic Study of Hausa Classic Novels: Shaihu Umar, Ruwan Bagaja and Kitsen Rogo." Kundin Digiri Na Uku [PhD]. Kano: Jami'ar Bayero. (A. M. Bunza and M. A. Noofal, eds. (2013). Ruwan Bagaja in Perspectives: Eight Decades of a Hausa Masterpiece in Prose (1933-2013). UNICAIREO/ UMYUK). I. Malumfashi (2006) has also referred to the winning essays as "Hausa Classic Novels" (ibid.: 154).

${ }^{7}$ This article is greatly indebted to Graham Furniss's Poetry, Prose and Popular Culture in Hausa (Washington D.C.: Smithsonian Institution Press, 1996).
} 
conditions for the emergence and consolidation of the canon of the Hausa prose fiction in both the Hausa language and in translation into English. This has been the case with both Ruwan Bagaja and Shaihu Umar. In the process of exploring the role played by the university critics, I will also highlight the features the critics have found with the winning essays which are similar to the ones used by other critics for their evaluation of African literary works in European and African languages. But before the university critics, let us first examine the role played by the British colonial administration in the promotion of Hausa language and culture through publications in Hausa.

\section{The Role of the British Colonial Administration in the Promotion of Hausa Language and Culture through Publications in Hausa}

The French colonial administration's assimilation policy attempted to thwart the development of indigenous languages and cultures through its efforts to promote the French language and civilization (for a more in-depth analysis on this issue see Oumarou, 2002; 2007, 2008, 2012). The British cultural policy, however, was more accommodating towards local cultures and languages which led to a parallel development of these cultures alongside the English language and civilization. As a matter of fact, in the late 70s Pathé Diagne already noted some different impacts of the French and British colonial policies on some Francophone and Anglophone writers in West Africa, especially in their attitudes toward their national languages and cultures. For Diagne (cf. Oumarou 2002: p. 215), the issue of national languages and cultures has been central in the preoccupations of the younger generation of writers such as the South African Mphalele trained in the Bantu school and the Nigerian Soyinka and Ladipo trained in the Yoruba language and tradition precisely because of the relative importance given to the promotion of local languages and cultures by the British colonial administrations.

As a result of a less hostile colonial policy vis-à-vis the local languages, there has been indeed some encouragement from the British colonial administration to produce reading materials in some Nigerian languages such as Hausa (Skinner, 1980; Furniss, 1996). The first beneficiaries of the teaching of Hausa were the colonial administrators themselves. But as Neil Skinner (1980: p. 167) observes, "The effect of teaching Hausa to the British did... have an important result on Hausa literature in that the British were not only administrators but also educators and were to make decisions regarding the script and books which would be used in the schools." The great architect of this policy was Lugard who, according to Skinner, "decided in favor of Hausa Roman script" (Emphasis added). Of course, Lugard's main purpose was not just to promote the Hausa language and culture. On the contrary, Skinner explains that "His main reason, as always, was a practical one: to provide a means by which Hausas could eventually become clerks for government and the [western] commercial firms" (Skinner, 1980: p. 167, note 1). 
But training some Hausas to become clerks was only one objective out of many. Muhammad Tahir Mallam (2013) (in Bunza \& Noofal, 2013: p. 153) has also uncovered some hidden designs that neither Lugard nor East could openly admit at the time. For Mallam, these designs constitute

[T] wo defining moments in the educational and literary development of the Muslim Hausa people of Northern Nigeria. One, it stunted and terminated the widespread development of a localized and indigenous literary tradition based on the Ajami writing script as well as on formal Arabic. Two, it marked the beginning of the widespread Romanization of Muslim Hausa literary and educational (western) texts. The new Romanized script [was] part of the grand design to arrest the dominant Islamic influence by eroding the significance of the formal Arabic script, particularly its domesticated version, the Ajami script... (Italics added) ${ }^{8}$.

But for Skinner, the decision to teach Hausa to the British and later on to the Hausas themselves has had a positive impact on Hausa language and literature. Muhammad Lawal Amin (in Bunza \& Noofal, 2013: p. 498) seems to support this positive claim in the abstract of his article where he explains that the article "seeks to further re-echo the colonial impact through its agent, R. M. East, and its institution, Translation Bureau, on the mode of documentation and dissemination of Hausa literary genres, as well as its colonial, deliberate, but wily attempt to transform their traditional didactic ends" (italics added). As a result, Amin calls the winning essays "colonial novel[s]". He also adds that these winning colonial novels have contributed to the spread and development of the Hausa Language. Moreover, the colonial administration's effort ${ }^{9}$ in the promotion of the Hausa language and literature reached a turning point with the organization of a literary contest in $1933^{10}$.

The emergence and development of Hausa imaginative prose fiction written in the Hausa language in Roman alphabet has in fact been linked to the literary

${ }^{8}$ See also Alio Mahaman. (2012). "La dimension culturelle de la résistance anticoloniale au pays hausa.” In Etudes Sahéliennes. No. 6. Octobre 2012. Pp. 59-72.

${ }^{9}$ See the following works from A.M. Bunza and M. A. Noofal, eds. (2013) all of which praise the role played by the colonial administration in the promotion of the Hausa language and literature: A.R. Bakura's (2012) dissertation entitled: "Gudummuwar Turawa wajen samuwa da ginuwar adabin Hausa”, Kudin Digiri Na Uku [PhD], Jami'ar Usmanu Danfodio, Sakkwato. Like Bakura, A. Ada$\mathrm{mu}$ (2009) equally shows a recognition of the effort of Rupert East in particular in the promotion of Hausa literature; Adamu's dissertation is entitled: "Rupert Moultrie East: Gudummuwarsa ga Adabin Hausa, da kuma Sharhi Kan Wasu Ayyukansa Na Adabi", Kundin Digiri Na Uku [PhD], Kano, Jami'ar Bayero; and H. Abbas' (2009) thesis entitled: "Gudummuwar Hukumar Wallafa Littattafai ta Arewacin Nijeriya Wajan Habaka Adabin Hausa 1966-2006”, Kudin Digiri Na Biyu [MA] a shashen Nazarin Harsunan Nijeriya, Jami'ar Usmanu Danfodio, Sakkwato.

${ }^{10}$ Two articles from Bunza and Noofal mentioned above have caught my attention as an illustration of the role of this literary contest in the development of Hausa prose fiction. The articles are: Malumfashi, I. (1996), “The Making of Abubakar Imam's Ruwan Bagaja: a Preliminary Investigation", a Paper Presented at Duniya Conference organized by the Association of Nigerian Authors, Kaduna State Chapter, at Arewa House, Kaduna. Malumfashi, I. and Aliyah, A. (2006), "Writing Competition and the Development of Hausa Novel", a Paper Presented at the $4^{\text {th }}$ Conference of Literature in Northern Nigeria, organized by the Department of English and French, Bayero University, Kano, 15 - 17 November 2006. 
contest of 1933 organized by the British colonial administration as an experiment to produce written literature in Hausa (Skinner, 1980; Furniss, 1996; Bunza \& Noofal, 2013) for schools and general readership in northern Nigeria. Writing back to one of the winners of the competition, Abubakar Imam, about his winning essay, Ruwan Bagaja, Rupert East, who was the major organizer of the contest, had the following encouragement addressed to the laureate:

"I hope you will write another book. If it is as good as the last I will certainly get it published for you. I think you have got the gift of writing, and there is no reason why it should not be a very profitable hobby for you. As soon as people get the idea of reading and buying books we shall be able to publish larger editions, and give a bigger percentage to the authors" (qtd in Furniss 1996: p. 25; italics added).

The institution in charge of the promotion of local publications in Hausa was the Translation Bureau which, according to Furniss (1996: p. 35) was created in 1930 and it kept the same name until 1934 when it became the Literature Bureau. From 1935, this bureau became Gaskiya Corporation with the Northern Regional Literature Agency (NORLA) as its publication department. Finally, Gaskiya Corporation became the Northern Nigerian Publishing Company (NN-PC) which was to dominate the publication of Hausa manuscripts until the emergence of new and private publishing companies very active today. In fact,

"The NNPC has [had] a unique position in northern Nigeria as the inheritor of the booklist of what was, for many years, the sole Hausa-language publisher in Nigeria. (...) Down the years it has been the editorial policies, the sense of purpose, and the commercial circumstances of the Gaskiya Corporation that have had the major influence on the picture of what has come to constitute Hausa written literature" (Furniss, 1996: p. 13).

Rupert East's continuing institutional support for the promotion of local publications in Hausa is further illustrated by the following comment by Furniss (1996: p. 35):

From the late 1930s, East had been pressing the colonial government to expand the activities of the Literature Bureau. East's dream was the foundation of a community of Nigerians and Britons living and working together, working side by side on the various crafts and skills of the publishing business: writers of school books, journalists, editors, illustrators, managers, printers, binders, distributors and sellers. This was the idea behind the Gaskiya Corporation which he [Rupert East] finally managed to sell to the then governor of Nigeria, Sir Arthur Richards.... The ideals behind the Corporation, framed in the colonial views of the time, were set out by East in 1946, focusing upon the development of the Corporation's newspaper, Gaskiya Ta Fi Kwabo ${ }^{11} \ldots$.

Following the example of Lugard, East wanted to go beyond the initial goal of

${ }^{11}$ Skinner reports that "The original purpose of its [Gaskiya Ta Fi Kwabo's] founding was to counteract German and Italian [second world] war propaganda." (Skinner, 1980: p. 168). 
Gaskiya which was to counteract the German and Italian war propaganda during the second Great War. So he tried to create the conditions for the emergence and development of a Hausa creative writing and readership tradition leading to the production of prose fiction and other Hausa teaching materials. He was convinced that " $[\mathrm{T}]$ here is a moderate and rapidly growing number of literates in the vernacular, particularly in Hausa, written in roman script. But until recently there has been no literature, and very little 'reading matter', for them to make use of their ability when they have got it. We [the colonial administrators] have taught them to ride, but have given them no horses" (East qtd in Furniss, 1996: p. 14).

The legacy of East's actions, as illustrated through Gaskiya Corporation and his personal writings on Hausa literature, is still a reality in today's independent Nigeria and the different academic works mentioned earlier on both the colonial administration's efforts and on the winning essays constitute a good testimonial as well as an attempt to "rehabilitate" the colonial positive initiatives for the development of local languages and cultures. As a consequence, I think it is also safe to say that such a legacy can be found in other countries colonized by Britain. In this respect, it is relevant to point out the observation made by Bernth Lindfors (1989: p. 209) as a result of his analysis of 134 literature courses offered in about 41 universities in Anglophone Africa in the 1970s. What came out of Lindfors' analysis is that "Most African universities English Departments display an understandable preference for teaching local literature (i.e., literature produced by native sons and daughters) and sometimes there are special courses set up to survey-'Zimbabwean literature' at the university of Zimbabwe, 'Nigerian literature' at various Nigerian campuses, 'South African literature' at the university of Lesotho, for instance."

Today such preferences are timidly manifested in some Francophone universities French Departments or in Francophone universities English Departments as well. Yet the teaching of local literatures is an important step into what Lindfors calls the "decolonization of literature study" well under way in the Anglophone universities he visited for his data collection. In other words, the decolonization of literature study in the Anglophone universities is a legacy of the British colonial policy in the fields of local cultures in general and local literature in particular. On this issue Abdou Moumouni, a scholar from the francophone Republic of Niger, has been explicit about what he considered as the positive impact of the English colonial policy vis-à-vis the local languages and cultures. Moumouni sees the difference "not in any philanthropic tendency of English colonization compared with the French, but in the objectively greater possibilities of cultural development which flow from even the partial use of African languages in schools" (qtd by Fredric Michelman in a pioneering article titled "French and British Colonial Language Policies: A Comparative View of their Impact on African Literature." Research in African Literatures 26/4 (Michelman, 1995: p. 220; emphasis added).

In the field of African literature, which is our concern here, two other impor- 
tant symbols of the English colonial legacy are worth mentioning: they are the literary competitions that were organized by what Furniss (1996: p. 33) has called the "Descendants of the 1934 Vintage" or the successors to the Literature Bureau symbolizing the colonial heritage. The first of these literary competitions, notes Furniss, was organized by the Northern Nigerian Publishing Company (NNPC) which is the direct descendant of the colonial Literature Bureau and the second competition by the Nigerian Federal Ministry of Culture to boost the national cultural development.

As Furniss has already noted, these competitions led to a good harvest of literary products which marked a rupture with both the content and style of the previous works (Emphasis added). Furniss has especially in mind here the winning essays that have become Hausa classics in the sense that since the writings of the 1930s (period in which the essays were written) the latter have been considered as a reference and models by the younger writers who either get their inspiration or mark their deviance from them. In either case, however, these Hausa classics are used by the literary critics to evaluate the younger writers to show the latter's conformity or departure from what has become the Hausa canon.

Furniss has attributed the younger writers' stylistic and thematic departure from these classics to modernity symbolized by the economic growth with its concomitant social inequality and injustice: "The most recent flowering of prose-writing is to be seen in the products of the Nigerian boom of the late 1970s and early 1980s, which departed radically from the earlier styles of writing" (Furniss, 1996: p. 33; my emphasis); that is to say the writings of the 30s, 40s, 50s and 60s. The stylistic and thematic departures by later prose writers from the earlier classics correspond to the criteria 1 and 6 out of the six criteria elaborated by the university critics mentioned above to characterize a literary classic or canon.

By and large, these Hausa classics have met at least five out of the six criteria proposed by Riesz above. The criterion that has yet to be met is the international fame for the authors and their works even though some of them have already been translated from Hausa into English and have been taught in various universities in Africa and outside. So let us now explore the role of the university critics, both Hausa and non Hausa, in the selection and promotion of an inchoate corpus of Hausa masterpieces.

\section{The Role of the University Critics in the Selection and Promotion of Hausa Literary Masterpieces in Prose}

The "Famous Authors' Reputation Test" designed by Bernth Lindfors in 1979 "shows no mercy on writers whose works and lives do not attract commentary. The unexamined literary career is not worth much in a noisy marketplace of ideas. To be famous, to be reputable, to be deemed worthy of serious and sustained consideration, an author needs as much criticism as possible, year after year after year. Only those who pass this test of time-the test of persistent pub- 
lished interest in their art-will stand a chance of earning literary immortality" (Lindfors, 2006: p. 118).

This necessary critical activity, which is part of the critical canon that usually precedes the canonization of authors, is more often the activity of teachers in general and of university teachers in particular. In that sense, Lindfors' commentary is shared by many other university critics such as Riesz who carried out his analysis of the canon formation process in African literatures based on the Dictionnaire des écrivains francophones classiques. Afrique subsaharienne, Caraibe, Maghreb, Machrek, Océan indien (Paris: Honoré Champion, 2010). Edited, prefaced and fore-worded by university professors, this Dictionnaire is the result of a collaborative effort by forty eight university critics from France, Africa, Maghreb, Machrek and Indian Ocean. Another example is the Dictionnaire des auvres littéraires négro-africaines de langue française, des origines à 1979 (Paris: ACCT, 1983) edited by Ambroise Kom, another University scholar. And the list of these kinds of works is long.

The above examples are an illustration of the relative importance ${ }^{12}$ of the university as an institution and of the university professors and their students as major actors in the canon formation process. In their introductory commentary on the Dictionnaire (2010), the contributors claim that by attaching the tag of "classic" to the authors they have analyzed, the Dictionnaire "engages the authors in a process of a more institutional literary consecration" (les [the authors] "engage dans un processus de consécration littéraire plus institutionnelle") (Riesz 2011: p. 148; italics added). On the other hand, however, the authors who have not been selected in such a delicate process will not "pass the test of time" nor "stand a chance of earning literary immortality" as Lindfors (2006: p. 118) would argue.

Rachel Sauvé (2001: p. 11), another university critic from Canada, echoes Lindfors' commentary when he claims that "The literature excluded from the [university] institution is marked by the anonymity in which its authors are confined" ("La littérature exclue par P institution [universitaire] est marquée par l'anonymat où ont sombré ses auteurs") (italics added). In the same line of thought, Alastair Fowler (1979: p. 99) adds that even the university critics themselves are often influenced by the critical canon or the criticisms they read about the works they are analyzing: "For most critics, indeed, the literature their work relates to is not that listed in bibliographies, but the far more limited areas of interest marked by repeated discussion in [scholarly or learned] journals... From this [critical] canon, countless considerable authors are excluded" (italics added) based on the criteria set up by the academic institutions. But the fundamental question is: how do we establish the link between the university and the canonization of a work or an author?

\footnotetext{
${ }^{12}$ In fact, the universities are not the sole actors in the canon formation process. Alastair Fowler (1979) claims that "The official canon is institutionalized through education, patronage, and journalism". "Genre and the Literary Canon". New Literary History. (11.1 autumns, 1979; italics added): 98. http://www.Jstor.org/stable/468873 Accessed on 02/10/2012.
} 
In the same line of thought, Riesz has asked more interesting questions which aim at discerning the link between the university, the critic and the author either already canonized or yet to be canonized: "Is an author a classic", Riesz wonders, "because he is read and commented in classrooms? Or is his admission into schools' programs effective only after the judgment by the critics who have considered him as worthy of belonging to the group of the 'best' or the 'excellent' authors?" (my translation) ${ }^{13}$. The quote from Lindfors mentioned above suggests that to become a classic an author has indeed to be read and commented on in classrooms over a long period of time. But from the contributors to the Dictionnaire (2010), Riesz has noted a rather mixed answer that verges on "A hesitation between a canonization already effected and which has been accepted, and aesthetic judgments that tend to show that an author is worthy of the label of a 'classic'. In other words, either an author is declared 'classic' because he is taught in programs and studied by the university critics, or an author is considered worthy of all this, and critics try to argue in favor of his canonization" (my translation $)^{14}$.

With regard to the Hausa corpus on prose fiction under our investigation, the canonization process seems at its very beginning, as it is the case with African literatures in general. Once again, Lindfors (1989: p. 215) in his pioneer research on canon formation in Anglophone African universities twenty years ago concluded that the canon of African literature was "still in a state of creative gestation, hardly anything about it [was] permanently fixed and immutable". That was in 1989. In 2005, Mouralis thought that the African literatures in African and European languages had reached their maturity symbolized by the emergence and consolidation of classics.

While Lindfors' remark about the creative gestation of canon in African literatures is certainly correct, various studies on canon formation in general have come to the same conclusion concerning the changing nature of canon in relation to period and new tastes. So for the Hausa prose fiction alike it is important to first explore the current available mass of critical work mostly on the winning essays of the 1933 literary competition in order to distinguish the authors and works already canonized and those on whom "aesthetic judgments [are made] which tend to show that an author is worthy of belonging to the shelves of the classics" ("des judgments esthétiques [are made] qui tendent à montrer qu'un auteur est digne d'accéder au rayon des 'classiques"”) (ibid.).

In this study, however, my investigation is limited to the impressive 762 entries under the general bibliography in Graham Furniss' Poetry, Prose and Popular Culture in Hausa already mentioned earlier. Out of the 762 entries, only 25

\footnotetext{
13“Un auteur est-il 'classique”, Riesz wonders, "parce qu'il est lu et commenté dans les classes? Ou bien son entrée dans l'enseignement se fait-elle seulement après le jugement critique qui l'a jugé digne de figurer parmi les 'meilleurs', les 'excellents' auteurs?"

${ }^{14}$....une hésitation entre une canonisation déjà faite et qui semble aller de soi, et des jugements esthétiques qui tendent à montrer qu'un auteur est digne d'accéder au rayon des "classiques". En d'autres termes, soit un auteur est déclaré “classique” parce qu'il est enseigné selon les programmes et étudié par la critique universitaire, soit on juge qu'il devrait l'être, et l'on avance des arguments en faveur de sa canonisation (Riesz, 2011: pp. 148-149).
} 
entries are about either the winning essays or the two literary competitions the first of which is the origin of the essays. And since the existence of critical works on given authors or works is an illustration of the interest of the critics and of the canonization process, it is therefore important to present the 25 entries classified under the different novels of our corpus as follows:

\section{Shaihu Umar.}

Aba'ali, R. M. (1982). Jigogin Shaihu Umar: dangantakarsu ga halayyan zaman Hausawa da abokan huldarsu. BA final paper. University of Maiduguri.

Abdulraheem, O. (1979). Myths of hierarchy and stability in islamic polity: The example of Shaihu Umar. Kano Studies (New Series), 1(4), 142-5.

Dahiru, S. U. (1984). Kwatanta labarin shaihu umar wasan kwaikwayo da zube. BA final paper, University of Sokoto.

La'ah, L. A. (1972). A comparison of two novels: shaihu umar and yawon duniya hajji baba. BA final paper, Bayaro University.

Nasr, A. A. (1984). Shaihu umar: A re-interpretation. In I. Y. Yahaya and A. Rufa'i (eds.). Studies in hausa language, literature and culture: Proceedings of the first international hausa conference, (July 1978, pp. 512-8). Kano: Bayaro University.

It is important to indicate that Shaihu Umar has met with an immediate success among Hausa speakers in Northern Nigeria. After its first publication in Hausa in 1934, it was reprinted six times by 1976. Prior to that, in 1969, it was translated into English by the British Hausa scholar, Mervyn Hiskett. This translated version also went into a second printing the following year. The production of a film Shaihu Umar in 1970 and a play Shaihu Umar by Umaru Ladan and Dexter Lindesay testifies to the novel's continued popularity among the Hausa speakers (cf. Oumarou (2015). An exploration of Hausa verbal art forms in Shaihu Umar. A Hausa novel. Advances in Literary Study, 3, 21-29.

http://dx.doi.org/10.4236/als.2015.31004).

\section{Gandoki:}

Mohammed, J. (1989). Kwatanta littafin iliya dan maikarfi da littafin gandoki. BA final paper, Bayaro University.

Mustapha, H. (1982). Kwatanta littafin gogan naka da littafin gandoki. BA final paper, Bayaro University.

Othman, F. (1981). Style in gandoki: A study of the fictional prose of alhaji muhammadu bello kagara. MA Thesis, SOAS, University of London.

Uba, S. I. A. (1982). Hausa literary genres in gandoki. BA final paper, University of Maiduguri.

\section{Ruwan Bagaja:}

Mohammed, M. Y. (1985). Kasancewar tatsuniyar ruwan bagaja tushen littafin ruwan bagaja na Dr abubakar imam. BA final paper, University of Sokoto.

Mora, A. (ed.). The abubakar imam memoirs. Zaria: NNPC.

Westley, D. (n.d.). Abubakar imam and the hausa oral tradition. Unpublished paper, Department of African Languages and Literatures, University of Wisconsin-Madison. 
Yahaya, I. Y. (1988/9). The literary works of Alhaji Abubakar Imam in perspectives. Harsunan nijeria 14: 71-98.

\section{Jiki Magayi:}

Ubah, M. T. (1989). Kwatanta littafin jiki magayi da littafin so aljannar duniya. BA final Paper, Bayero University.

\section{Idon Matambayi:}

Zagga, N. M. (1985). Salo da jigo da tsarin al'adun hausawa a wasan idon matambayi na gidan talabijin sakkwato. BA final paper, Bayero University.

There are also essays on the role and place of the two literary competitions organized by the colonial and post-independence administrations to initiate and encourage the Hausa people into writing and reading materials in Romanized Hausa alphabet. Some examples are as follows (Bunza \& Noofal, 2013):

Abdullahi, A. A. (1987). Tasirin adabin baka kan kagaggun littattafan zube na gasa ta farko (1933). BA final paper, Ahmadu Bello University.

Amina, A. (1987). Zamananci a kagaggun littafan zube na gasa to biyu (1979). BA final paper, Ahmadu Bello University.

Cosentino, D. J. (1978). An experiment in inducing the novel among the Hausa. Research in African literatures 9 (1), 19-32.

East, R. M. (1936). A first essay in imaginative African literature. Africa, 9 (3), 350-7.

Hayatu, H. (ed.). (1991). 50 years of truth: The story of gaskiya corporation 1939-1941. Zaria: Gaskiya corporation.

Iliya, R. M. (1992). Jigon jarunta a uku daga littattafan NORLA. BA final paper, University of Sokoto.

Sani, A. A. (1989). Neo-colonialism and literature in nijeriya: The case of the northern nigerian publishing company

limited, Zaria, 1966-1980's. Paper presented at the eight ibadan annual African literature conference, Ibadan University, 6-9 March.

Skinner, A. N. (1980). NORLA: An experiment in the production of vernacular literature 1954-1959. Revues des langues vivantes 36 (2), 166-75.

Sa'id, A. (1985). Nazarin yanayi a rubutatun kagaggun labaran gasa na hausa. MA thesis, Ahmadu Bello University.

Sule, K. (1986). Salon bida a kagaggun rubuttattun labaran Hausa na gasa ta farko (1933). BA final paper, Ahmadu Bello University

Tsiga, H. I. (1987). Tasirin addinin Musulumci a kagaggun rubutattun litafan zube na gasar farko (1933/34). BA final paper, Ahmadu Bello University.

More references to critical works are found in Bunza and Noofal (2013) on the five winning essays. Of course Ruwan Bagaja, which is the subject of the book, has the lion's share. In addition, the very fact that most of the critical works about the winning essays consist of BA and MA theses and PhD dissertations is an indication that the essays have become part of university syllabuses in Northern Nigerian Universities. The existence of significant critical works on these essays can therefore be seen as a manifestation of interest by university critics in 
line with their role as actors and mediators in the canonization process about authors and their works.

\section{Concluding Remarks}

The above exploration has shown that by and large the Hausa classics examined so far have met at least five out of the six criteria proposed by Riesz. The sixth criterion that has yet to be met is the international fame for the authors and their works even though Ruwan Bagaja and Shaihu Umar have already been translated from Hausa into English and have been taught in various universities in Africa and probably outside of Africa. But the marginalization of African literatures in African languages remains as a challenge as Furniss and other critics have demonstrated. However, today it is safe to talk about a Hausa canon in the prose fiction in the Hausa language. This has been demonstrated through the exploration of our corpus of the five winning essays resulting from the literary contest organized by the British colonial administration in 1933. This year has also served as our historical reference or what Riesz has called the historical moment which is important in defining a canon for a given literature. The most powerful testimonial to this claim is the very title of the epoch-making critical work on the novel Ruwan Bagaja published in 2013 to celebrate the eighty years of the novel's active service in the Hausa literary history as well as its academic relevance to Hausa studies in general. The subtitle of the critical work is even more revealing of the importance of the winning essays for the canon formation process in the Hausa prose fiction: Eight Decades of a Hausa Masterpiece in Prose (1933-2013). The same claim can be made for the other four winning essays in particular and for many others that have not been the focus of this study.

\section{References}

Bunza, A. M., \& Noofal, M. A. (Eds.). (2013). Ruwan Bagaja in Perspectives: Eight Decades of a Hausa Masterpiece in Prose (1933-2013). Cairo: Unicairo/Umyuk.

Dérive, J. (2005). L'approche critique des littératures en langues africaines. Notre Librairie, $160,29-32$.

Fowler, A. (1979). Genre and Literary Canon. New Literary History, 11, 97-119. https://doi.org/10.2307/468873

Furniss, G. (1991). De la fantaisie à la réalité dans la littérature haoussa en prose. Suivi de pourquoi étudier la poésie haoussa?31. Centre d'étude d'Afrique noire.

Furniss, G. (1996). Poetry, Prose and Popular Culture in Hausa. Washington DC: Smithsonian Institution Press.

Lindfors, B. (1989). The Teaching of African Literature in Anglophone African Universities: A Preliminary Report. In T. Hale, \& R. Priebe (Eds.), The Teaching of African Literature (pp. 203-215). Washington DC: Three Continent Press and the African Literature Association.

Lindfors, B. (2006). A Last Shot at the $20^{\text {th }}$-Century Canon. In E. N. Emenyonu (Ed.), New Directions in African Literature 25 (pp. 109-119). Ibadan: Africa World Press.

Mallam, M. T. (2013). Structure and Narrativity in Abubakar Imam's Ruwan Bagaja. In A. M. Bunza, \& M. A. Noofal (Eds.), Ruwan Bagaja in Perspectives: Eight Decades of a 
Hausa Masterpiece in Prose (1933-2013) (pp. 153-162). Cairo: Unicairo /Umyuk.

Michelman, F. (1995). French and British Colonial Language Policies: A Comparative View of Their Impact on African Literature. Research in African Literatures, 26, 216225.

Mouralis, B. (2006). Qu'est-ce qu'un classique africain? Notre Librairie, 160, 35-40.

Oumarou, C. E. (2002). Les traditions orales comme fondement de la connaissance et du développement. Mu Kara Sani: Revue de l'Institut de Recherches en Sciences Humaines (pp. 199-217, Vol. 10, fascicules 1-2). Université Abdou Moumouni.

Oumarou, C. E. (2007). Décoloniser la langue française, apprivoiser la francophonie: Les leçons de l'anglophonie. SAFARA: Revue Internationale de Langues, Littératures et Cultures, 11, 127-142.

Oumarou, E. C. (2008). Face à la francophonie: Comment être francophone et africain? In B. Jewsiewicki, \& E. Nimis, (Eds.), Expérience et mémoire: Partager en français la diversité du monde (pp. 50-70). Paris: L'Harmattan.

Oumarou, E. C. (2012). Francophonie in Africa South of the Sahara: Specificity, Challenges and Perspectives. SAFARA: Revue Internationale de Langues, Littératures et Cultures, 11, 17-36.

Oumarou, C. E. (2015). An Exploration of Hausa Verbal Art Forms in Shaihu Umar. A Hausa Novel. Advances in Literary Study, 3, 21-29.

https://doi.org/10.4236/als.2015.31004

Riesz, J. (2011). A propos des «classiques africains.» Quels modèles pour un canon des littératures africaines? Etudes Littéraires Africaines, 32, 147-156.

https://doi.org/10.7202/1018651ar

Sauvé, R. (2001). Canon littéraire et enseignement de la littérature française au Canada anglais: L'exemple des femmes auteurs. The Canadian Journal of Higher Education/La revue canadienne d'enseignement supérieur, XXXI, 1-22.

Skinner, N. (1980). An Anthology of Hausa Literature. Zaria: NNPC.

\section{Submit or recommend next manuscript to SCIRP and we will provide best service for you:}

Accepting pre-submission inquiries through Email, Facebook, LinkedIn, Twitter, etc. A wide selection of journals (inclusive of 9 subjects, more than 200 journals)

Providing 24-hour high-quality service

User-friendly online submission system

Fair and swift peer-review system

Efficient typesetting and proofreading procedure

Display of the result of downloads and visits, as well as the number of cited articles

Maximum dissemination of your research work

Submit your manuscript at: http://papersubmission.scirp.org/

Or contact als@scirp.org 